\title{
Learning in College: Beyond the Classroom
}

\author{
Savitha Suresh Babu*
}

\begin{abstract}
Learning in college often extends beyond classrooms and formal instruction. Various forms of student organisings can allow for learning beyond institutional curricula. In this paper, using two examples of collective mobilisations, I argue for paying keener attention to the informal within formal education spaces. Both the instances under discussion occur around the space of the hostel - located within the formal educational institution and yet, away from the formalised processes of learning and teaching. In varied ways, however, the forms of conversation that marks the coming together of students, has pedagogic significance. Specifically, conceiving students mobilising as an instance of anti-caste assertion or against implicitly accepted gender norms, I argue, provides students newer ways of thinking about the world - and must thus be conceptualised as learning. Not only are these informal learning spaces significant for the varied ways they could impact students; they are also important in holding the possibility to question hegemonic practices in educational institutions, and society at large.
\end{abstract}

Keywords: Informal Learning, College Education, Student Collectives, Questioning Social Hegemony

"National Institute of Advanced Studies, Bengaluru, India; savithasureshbabu@gmail.com 


\section{Introduction}

College education is hardly ever only about classrooms or examinations. It is as much about conversations in canteens and corridors, cultural and political events, and friendships of many kinds. Given this reality, how do we think of learning in college beyond institutionally mandated curricula and evaluations? What are the forms of informal learning that occur in formal higher educational institutions?

In the past two years, students in several Indian universities have risen up against figures of authority, demanding social justice. Particularly, after the tragic death of a research scholar in the University of Hyderabad, conversations on equality (or the lack of it) in higher learning have obtained media attention. At a time such as this, what do students who come together to share their experiences or raise fundamental questions about the purposes of universities achieve? Are they not asking questions beyond what the curriculum expects or even encourages them to? Are they not, then, creating newer pedagogic possibilities and spaces of learning?

In an introduction to a volume on informal learning, the authors (Bekerman et al., 2006, p. 1) write, "we seek to free up the study of learning from constraining assumptions about traditional institutional arrangements and hegemonic definitions of what counts as "learning"". Could paying attention to informal interactions within formal institutions help challenge hegemonic definitions of learning?

The paper delves into this question within the specific historical, social and political realities of Indian higher education. Today, what might be called higher education in India is vast and diverse ${ }^{i}$. Over the past few decades, the enrollments within these institutions have increased. Historically, formal education had been confined to privileged caste groups. Even as enrollments of Dalit, including Dalit women studentsii has increased enormously, there are serious concerns that remain about social inclusion in higher educationiii.

Education of women, in general, has had a complicated history. While much sociological literature has shown how historically, 
women's education was part of preparing them for domestic lives (Karlekar, 1986; Chatterjee, 1989; Rao, 2007, 2008), some recent work has demonstrated how education has also brought forth new possibilities for Dalit women (Paik, 2014)iv.

Currently, while Dalit students have raised issues of discrimination of various kinds in higher educational institutions, women across caste and class groups talk of being subject to various forms of regulation and control. Educational institutions have often taken the role of "fictive parents" that often translates to close monitoring of adult women's relationships and lives. This cursory account of Indian higher education is important, to contextualise the two instances I will later pick to demonstrate forms of informal learning that take place through student collectives in formal educational institutions, and their significance.

I will begin by considering some ways in which "informal learning" has been conceptualised. Subsequently, I will recall two moments of student mobilisation, separated by time and context, and yet similar in questioning the different forms of societal dominance. In both instances, students come together in hostelsv to address material concerns. However, in the process, I believe, they learn from each other, and the processes they become part of. Here, I draw from a sociocultural understanding of learning (Vadeboncoeur, 2006) that,

mental functioning in individuals originates in social life, such as the everyday activities and interactions of families, schools, workplaces, and economic institutions, and human action is mediated by cultural tools and signs; that is, from speech and language to our use of machines such as computers, human action is mediated by what we use to make meaning (Wertsch, 1991). From this perspective, at the core of understanding learning is an examination of social practices (generally, what people are doing) and discursive practices (generally, what people are saying). (p. 247)

I argue that the mobilising efforts I will discuss, for many students, could have provided access to new social and discursive practices, and any effort that does so could be conceptualised as learning. 


\section{"Learning in places": Conceptualising informal learning}

Even some scholars (Livingstone, 2006) have sought to define informal education, they have discussed the difficulties of making clear demarcations between formal, non-formal and informal. For the limited purposes of this paper, however, I initially make the distinctions. Formal education is a highly structured and institutional engagement, from early childhood onto university education. Along with a fixed curriculum, institutional design and structure are rigid. Non-formal education is understood to be that which occurs outside these institutionalised structures, and could range from short-term courses to political meetings. Informal learning could occur in both formal and non-formal settings. Clarifying what is meant by informal learning, Schugurensky (2000) writes, "informal learning can also take place inside formal and non-formal educational institutions. In that case, however, the learnings occur independently (and sometimes against) the intended goals of the explicit curriculum" (p. 2). So, the learning I refer to is that which occurs within colleges or universities, but not necessarily learning which has institutional approval.

Based on awareness and intentionality of learners, Shrugensky (2000) classifies informal learning into three broad types - selfdirected, incidental and socialisation. While self-directed learning takes place with full awareness of the learner and socialisation occurs without explicit awareness, incidental learning lies somewhere in between. In the various examples the author offers to explain the incidental form of informal learning, the last one is

A group of neighbours participate in local democracy, and through this process they learn about municipal politics; although they didn't join the process with a learning objective in mind, they realise that they have gained new skills and knowledge that allow them to participate more effectively in democratic deliberation and decision-making. (Shrugensky, 2000, p. 4)

The form of learning I refer to in this paper falls perhaps closest to this category. I talk of students facing different forms of social discrimination, coming together to challenge institutional authorities. They come together for the immediate cause of 
freedom or dignity - but in the process, raise larger questions of caste and gender as forms of social (dis)privilege. The point at which Shrugensky's conceptualisation seems inadequate for my purposes here is that the learnings I talk of are not entirely incidental. Unlike the example of neighbors participating in municipal politics, there is greater self-awareness of the structural social factors bringing them together, even as in the process of coming together, more maybe learnt.

Another way of thinking through the forms of learning I allude to maybe of "situated learning" that "occurs within and outside of institutional contexts and occurs in participation and practice with others" (Lave and Wanger, cited in Froer et al., 2012, p. 337). They write "they emphasised the multiple and continual modes in which learning takes place in everyday life through watching, practicing, and having an active role in activities undertaken with and in relation to others. It is through such a role that learners gain understandings and also generate knowledge themselves". By mobilising as student collectives, at particular moments of time, in formal educational institutions, I argue that certain "communities of practice" are made possible through which actors are rendered both teachers and learners.

The first empirical instance I discuss will be of Dalit student collectives, which led in substantial ways to the literary and social Dalit movement in Karnataka. The second is the contemporary movement by a group of women students challenging discriminatory rules within hostels. While the collectives address different concerns, and at different time periods and regions, they are similar in questioning hegemonic social practices. I now offer a brief account of both the movements.

\section{Learning to study and struggle: Emergence of the Karnataka Dalit Sangharsh Samiti (DSS) in student hostels in Karnataka}

The role played by students, during the emergence of a new wave of the Dalit movement in Karnataka in 1970's was key. The movement was in many ways a reaction to the statement made by Basavalingappa, the social welfare minister at the time to Kannada literature as Boosa (cattle feed). He made this remark, in order to refer to the clear upper-caste dominance of the literary world. 
Several pro-Kannada organisations, particularly non-Dalit college students took out agitations against the minister. At the time, Dalit students, too, came out to defend Basavalingappa, and take the Boosa comment to generate conversations around caste and discrimination. Susie Tharu and K. Satnarayana (2015), in an introduction to a collection of Dalit writings, say, "A majority of those who rallied around Basavalingappa at the time of the attacks were first generation Dalit students who, through reservations, had made their way from villages into the university (though some non-Dalit progressive writers and rationalists also came to his support). Universities and colleges, and especially the social welfare hostels, were hubs of activity, and soon became the studios in which a whole new Kannada literature took shape (p. 6).

In several news reports cited in a book on the Dalit movement in Karnataka (Shetty, 1978) we learn that this was also the time when open confrontations took place between caste-Hindu boys and Dalit boys in university hostels. Quoting one such report (Deccan Herald, 1975; Shetty, 1978), "Knocking on the doors of the rooms of the scheduled cast students, the goondas were alleged to have hurled abuses at them: "Holeyaru, Madigaru". They are fit for scavenging and boot-polishing but are eating with us at our cost". One of the boarders, quoted in the report says, "If this were to be the plight of the educated scheduled caste people in a metropolitan city under the very nose of the Government, they can imagine the treatment meted out to their illiterate brethren in rural areas".

In recounting this period of history, Shetty (1978) writes, "As a spontaneous upsurge it became the very first protest offered by Dalit students on a state-wide scale.....The Dalit students who were singled out and beaten up by the caste Hindu boys, for the first time, had an opportunity to think of the reasons for their degradation and deprivation. They held group meetings in hostels, under the trees, and in hotels to debate the caste system, untouchability, and the different speeches of Basavalingappa and the thoughts of Ambedkar". (pp. 40)

Dalit students here may have come together to support a leader, and address their material concerns of safety. However, the nature of conversations and debates led to a social movement. Significantly, a large number of Dalit writers in the Kannada 
literary world emerged through this period, as did the organisation Dalit Sangharsh Samiti (Tharu \& Satyanarayana, 2013). For students who were part of this movement, the conversations and debates clearly helped them learn much more than what was expected of them in formal institutions.

\section{Breaking the hostel cages: Pinjra Tod}

The other movement I wish to discuss is the contemporary movement by groups of women students in Delhi. Started in 2015, protesting against discriminatory curfew rules in hostels, the movement has grown over the last two years. Young women through the movement have begun to challenge "deeply entrenched attitudes about women's bodies-be it a ban on wearing shorts in some hostels, or being forced to wear a dupatta over laboratory coats, or the lack of enough accommodation"vi. By holding public consultations with women studentsvii over the nature of problems they face, the movement has generated conversations over student shelters and the ways in which class, caste and gender intersect in the availability (or not) of safe places to stay. In the report, for instance, Dalit women students talk of how certain PG's refuse to rent out spaces to them/if they do, insist certain vessels are not touched. Clearly, there are material concerns that help bring these young women together. However, in the process of sharing their concerns as a collective, I believe new ways of thinking about their place in the world are acquired.

\section{Learning as "collectives"}

I used these two specific instances of socio-political mobilisation as they were based on students mobilising as collectives, without any explicit connect to electoral politics. These examples show how student mobilisations, without any clearly laid out pedagogic agendas, can be spaces of enormous learning. In the beginning of the paper, I had argued that paying attention to informal spheres can break hegemonic conceptions of learning. While that is definitely the case, at the end of this discussion, I also submit that the forms of learning discussed here could also challenge social hegemonies of varied kinds. In the first instance, students who were part of the early DSS asked questions of unstated implicit caste-based domination of various spheres. In the second instance, 
students are taking on gendered (and "often accepted") rules that limit the freedoms of women students.

Livingstone (2006) writes of how informal learning "occurs in irregular time and space patterns. ... You can learn life-course shaping influential knowledge at any place within a short time". Being part of student mobilisations, or being influenced by them in various ways could provide students significant knowledge to navigate the social worlds they inhabit.

At the same time, it might be important to note that these forms of informal learning are significant not just for the student-learner, but perhaps for the formal structure of education too. In articulating Phule-Ambedkarite pedagogical perspectives, Sharmila Rege (2010) writes of them being different not only in terms of learning and teaching "but also dissenting against that which is learnt and taught by dominant cultural practices". Drawing from the writings of Phule who conceptualises education as the "trutiya ratna", she makes a case for meaningful education as that which can unmask the relationship between knowledge and power. In such a conceptualisation of meaningful education, the "informal" holds potential to change the dynamics of the "formal" by bringing in new practices and questions to the classroom and curriculum.

\section{References}

Bekerman, Z., Burbules, N. C., \& Keller, D. S. (2006). Learning in places The informal education reader. New York: Peter Lang.

Chatterjee, P. (1989). Colonialism, nationalism, and colonialized women: The contest in India. American Ethnologist, 16(4), 622-633.

Department of Higher Education, Ministry of Human Resource Development. (2013). All India survey on higher education. New Delhi: Government of India.

Froer, P., \& Portisch, A. (2012). Introduction to the special issue: Learning, livelihoods, and social mobility. Anthropology Education Quarterly, 43(4), 332-343.

Karlekar, M. (1986). Kadambini and the Bhadralok: Early debates over women's education in Bengal. Economic and Political Weekly, 21(17), WS25-WS31

Ministry of Human Resource Development. (2014). Educational statistics at a glance. New Delhi: Government of India. 
Paik, S. (2014). Dalit women's education in modern India: Double discrimination. London: Routledge, Taylor and Francis.

Rao, P. (2007).Women's education and the nationalist response in western India: Part I- basic education. Indian Journal of Gender Studies, 14(2), 307-316.

Rao, P. (2008), Women's education and the nationalist response in western India: Part II-higher education. Indian Journal of Gender Studies, 15(1), 141-148.

Rege, S. (2010). Education as Trutiya Ratna: Towards Phule-Ambedkarite feminist pedagogical practice. Economic and Political Weekly, 45(44), 8898.

Satyanarayana, K., \& Tharu, S. (2013). Introduction. In K. Satyanarayana \& S. Tharu (Eds.), From those stubs, steel nibs are sprouting: New Dalit writing from south India- Dossier II: Kannada and Telugu. India: Harper Collins.

Schugurensky, D. (2000). The forms of informal learning: Towards a conceptualization of the field. WALL Working Paper No.19, 2000, Centre for the study of Education and Work, University of Toronto.

Shetty, R. (1978). Dalit movement in Karnataka. The Christian literature society: Madras

Tilak, J. (2015). How inclusive is higher education in India? Social Change, $45(2), 185-223$.

Vadeboncoeur, J. (2006). Engaging young people: Learning in informal contexts. Review of Research in Education, 30, Special Issue on Rethinking Learning: What Counts as Learning and What Learning Counts, 239-278.

i There are 799 universities (public, private and open), and 39071 colleges according to AISHE 2016. 
ii While there were only 14 women per 100 men in higher education in 1950-51, the numbers have increased to $43 \%$ by 2011-12 (Tilak, 2015). If one considers enrolment of women from scheduled communities, there has been a substantial increase over the last decade. The Gross Enrolment Ratio (GER) for SC women in higher education increased from 3.6 per cent in 2000- 01 to 13.5 per cent in 2011-12. In the same period, GER for SC men increased from 7.7 per cent to 15.4 per cent. The GER for ST women increased from 2.6 per cent in 2000-01 to 9.6 per cent in 2011-12. In the same period, GER for ST men increased from 5.8 to 12.4 (AISHE, 2013; MHRD, 2014).

iii From overt discrimination to subtle ways in which the cultural background of Dalit and Adivasi students is devalued in elite university spaces, the experience of higher education can be traumatic for "quota students" (Anveshi law committee, 2002; Senthil Kumar Solidarity Committee, 2008; Azad, 2012; Ovichegan, 2014 among others).

iv Shailaja Paik in her work on the meanings education held for Dalit women shows how important education has been in navigating, and sometimes escaping multiple axes of oppression (Paik, 2014).

$\mathrm{v}$ as formally provided housing for students, they are spaces which lie in unclear spaces between the formal-informal dichotomy.

vihttp:/ / www.livemint.com/Leisure/z6E69WRoNJAyUuGU5yYwXO/H ow-Pinjra-Tod-spread-its-wings.html (last accessed on July 17, 2017)

vii https:/ / feminisminindia.com/2017/02/23/pinjra-tod-jan-sunwai/ (last accessed on July 17, 2017) 